\title{
PERTIMBANGAN VISUAL DAN FISIOLOGIS SEBAGAI KRITERIA PANEN KANGKUNG DARAT AKIBAT PEMBERIAN KAPUR DOLOMIT DI TANAH GAMBUT
}

\author{
DJOKO EKO HADI SUSILO \\ Dosen Program Studi Agroteknologi Fakultas Pertanian dan Kehutanan \\ Universitas Muhammadiyah Palangkaraya \\ Email :masdjoko_ns@yahoo.co.id
}

\begin{abstract}
The aim of this study is to observe visually and physiologically as consideration of criteria of Kale crop (Kangkong) because of giving dolomite lime in peat soil. This study was conducted in September to December 2015 in the city of Palangka Raya in Central Kalimantan.

The giving of dolomite lime as the treatment was done as many as 3 dose level, namely: $D_{1}=3$ tons $h^{-1} ; D_{2}=6$ tons ha ${ }^{-1}$ and $D_{3}=9$ tons ha ${ }^{-1}$ as many as 9 replications. Observation was done to height of plant (cm); the number of leaves (leave); the leaves area $\left(\mathrm{cm}^{2}\right)$, the leaves area index (ILD), fresh weight of harvest (g), and the fresh harvest index (IP) at the age of 21 and 28 days after planting (DAP). Fresh crop harvesting of Kale (Kangkong) was done by repealed (destructive). Analysis of the growth of leaves area, the leaves area index, fresh weight of shoot, and the fresh harvest index used Guritno and Sitompul methods (1995).

The result of this study showed that based on visual estimation and consideration of physiological indicators of Kale (Kangkong) growth in peat soil because of the giving dolomite lime, then criteria for the crop was considered can be harvesting starting at age 21 DAP and it did not need to wait until the plant at ages 28 DAP on all doses of giving lime (3-9 tons ha $\left.{ }^{-1}\right)$ because it has a physiological growth that support the harvest index that relatively high at $73.2-78.1 \%$ despite fresh harvest at age 28 HST also able to achieve a harvest index of 74.9-76.1\%. The result of this study suggested that fresh harvesting of Kale (Kangkong) that was repealed (destructive) should be beginning about age 21 DAP when planted in peat soil by using dolomite lime with a dose of 3-9 tons ha ${ }^{-1}$.
\end{abstract}

Keywords: visual, physiological, harvest criteria, Kale (kangkung darat), dolomite, and peat soil

\section{ABSTRAK}

Penelitian ini bertujuan untuk mengamati secara visual dan fisiologis sebagai pertimbangan kriteria panen kangkung darat akibat pemberian kapur dolomit di tanah gambut. Penelitian ini dilaksanakan pada bulan September-Desember 2015 di Kota Palangka Raya Kalimantan Tengah.

Pemberian kapur dolomit sebagai perlakuan dilakukan pada 3 taraf dosis, yaitu : $D_{1}=3$ ton ha ${ }^{-1}$; $D_{2}=6$ ton ha ${ }^{-1}$ dan $D_{3}=9$ ton ha ${ }^{-1}$ sebanyak 9 ulangan. Pengamatan dilakukan terhadap tinggi tanaman (cm); jumlah daun (daun); luas daun $\left(\mathrm{cm}^{2}\right)$, indeks luas daun (ILD), berat segar panen (g), dan indeks panen segar (IP) pada umur 21 dan 28 hari setelah tanam (HST). Panen segar kangkung darat dilakukan dengan cara dicabut. Analisis pertumbuhan luas daun, indeks luas daun, berat segar panen, dan indeks panen segar menggunakan metode Sitompul dan Guritno (1995).

Hasil penelitian ini menunjukkan bahwa berdasarkan penilaian visual dan pertimbangan indikator fisiologis pertumbuhan tanaman kangkung darat di tanah gambut akibat pemberian kapur dolomit, maka kriteria panen dapat dipertimbangkan bisa dilakukan mulai umur $21 \mathrm{HST}$ dan tidak perlu menunggu umur 28 HST pada semua dosis pemberian kapur yang diberikan (3-9 ton ha ${ }^{-1}$ ) karena telah memiliki pertumbuhan fisiologis yang mendukung indeks panen yang relatif tinggi sebesar $73,2-78,1 \%$ meskipun panen segar di umur 28 HST juga mampu mencapai indeks panen sebesar 74,9-76,1\%. Hasil penelitian ini menyarankan bahwa panen segar kangkung darat dengan cara dicabut sebaiknya dilakukan dimulai umur 21 HST apabila ditanam di tanah gambut menggunakan kapur dolomit dengan dosis 3-9 ton ha ${ }^{-1}$.

Kata kunci : visual, fisiologis, kriteria panen, kangkung, dolomit, dan tanah gambut 


\section{PENDAHULUAN}

Tanaman hortikultura yang berjenis sayuran daun pada umumnya berumur pendek, yang ditandai dengan saat layak dipanennya tanaman sebagai bahan sayuran. Hampir semua tanaman hortikultura sayuran daun mampu ditanam dan dipanen secara cepat sesuai penampilan pertumbuhannya hingga memasuki saat panen, namun seringnya penentuan saat panen hanya didasarkan pada umur tanaman atau faktor lain yang menjadi kebiasaan, sehingga sangat bervariasi saat panen yang digunakan diantara produk hortikultura sayuran daun. Bebarapa alasan digunakan untuk penentuan saat panen namun tidak didasarkan atas pertimbangan yang layak, padahal jenis tanamannya juga sama.

Salah satu jenis tanaman hortikultura sayuran daun adalah kangkung (Ipomoea reptans L.). Tanaman kangkung umumnya mampu dibudidayakan secara baik di daerah tropis sebagai sayuran. Kangkung mampu dibudidayakan secara lebih baik untuk memanfaatkan periode suhu panas yang panjang dengan sistem pengairan yang baik. Luther (2012) menjelaskan bahwa kangkung dapat ditanam di berbagai jenis tanah dengan memerlukan sinar matahari dan air yang cukup. Menanam kangkung di dataran rendah memungkinkan akan memberikan hasil yang lebih tinggi dibandingkan menanam di dataran tinggi.

Mengupayakan kuantitas produksi tanaman hortikultura sayuran adalah sangat penting, yakni dengan melaksanakan GAP (good agriculture practices) dan sebagai bentuk keberlanjutan rantai pemenuhan kebutuhan tanaman hortikultura sayuran ternyata memerlukan kelengkapan aspek berupa jaminan kualitas produk yang menyangkut mutu hasil panennya. Hal ini bisa didukung dengan penentuan saat panen yang tepat dengan didasarkan pada pertimbangan yang tepat pula, diantaranya menurut pertumbuhan tanaman.

Panen dan pascapanen tanaman hortikultura sayuran daun sangat berhubungan dan bergantung dengan sistem produksi produk hortikultura. Produksi yang baik mengakibatkan saat panen dan mutu panen menjadi baik juga sehingga bisa optimal sistem pascapanennya terhadap tampilan, tekstur, cita rasa, nilai nutrisi, keamanan, panjangnya masa simpan dan masa pasar produk hortikultura. Utama dan Antara (2013) menjelaskan bahwa saat panen dan pascapanen yang sesuai menjadi terasa penting dan harus dikembangkan untuk mengatasi respon yang beragam dan terjadi karena adanya perbedaan kultivar, stadia kematangan, daerah pertumbuhan, dan musim.

Umumnya produk panen sayuran daun berupa bentuk dan warna yang secara bersamasama memberikan penampilan dari produk hortikultura masih merupakan parameter penting di pasar perdagangan. Kesan di masyarakat juga penting diketahui sebagai sikap terhadap komponen mutu sayuran daun yang menyangkut cita rasa, tekstur, nilai nutrisi, dan tidak adanya kerusakan fisiologis sehingga menentukan arti produk hortikultura sayuran bagi masyarakat. Oleh sebab itu perlu diperhatikan masa (saat) panen, kuantitas dan kualitas hasil panen. Menentukan masa panen yang baik adalah selain menjaga mutu (kualitas) juga ada keuntungan pengaturan pola tanam dan pola panen sehingga ada efisiensi pemenuhan kebutuhan panen sayur 
terhadap keberlanjutan (kesinambungan) pemenuhan kebutuhan pasar menyangkut komoditas hortikultura sayuran daun.

Berdasarkan kondisi budidaya tanaman kangkung darat yang berpotensi secara berkelanjutan, maka penelitian ini memiliki tujuan untuk mengamati secara visual dan fisiologis pertumbuhan tanaman kangkung darat sekaligus digunakan sebagai pertimbangan kriteria panen kangkung darat sebagai akibat peningkatan kesuburan tanah oleh pemberian kapur dolomit di tanah gambut.

\section{METODOLOGI}

Penelitian ini dilaksanakan selama 4 (empat) bulan, pada bulan September-Desember 2015 di Lahan Kampus UM Palangkaraya Jl. Anggrek, Lingkar Luar Kelurahan Kereng Bangkirai, Kecamatan Sabangau, Kota Palangka Raya, Provinsi Kalimantan Tengah.

Percobaan budidaya tanaman kangkung darat jenis KANGKUNG BISI dilakukan dengan media tanam berupa tanah gambut pedalaman dengan kematangan gambut pada tahap saprik, sehingga untuk meningkatkan $\mathrm{pH}$ tanah dan mendukung ketersedaiaan unsur hara bagi pertumbuhan tanaman dilakukan pemberian kapur dolomit untuk mengurangi kemasaman tanah sekaligus sebagai upaya pemupukan. Pelaksanaan percobaan penanaman budidaya tanaman kangkung darat dilakukan menggunakan polybag ukuran $40 \times 40 \mathrm{~cm}$ dengan media masingmasing polybag seberat $5 \mathrm{~kg}$ tanah gambut.

Rancangan perlakuan berupa pemberian kapur dolomit pada tanah gambut yang dilakukan sebanyak 3 taraf dosis, yaitu : $\mathrm{D}_{1}=3$ ton $\mathrm{ha}^{-1}$; $\mathrm{D}_{2}=6$ ton ha ${ }^{-1}$ dan $\mathrm{D}_{3}=9$ ton ha ${ }^{-1}$ yang diulang sebanyak 9 kali. Pengamatan yang menunjang tujuan penelitian ini dilakukan terhadap tinggi tanaman $(\mathrm{cm})$; jumlah daun (daun); luas daun $\left(\mathrm{cm}^{2}\right)$, indeks luas daun (ILD), berat segar panen cabut (g), dan indeks panen segar (IP) masingmasing pada umur 21 dan 28 hari setelah tanam (HST). Panen segar kangkung darat dilakukan dengan cara dicabut. Analisis pertumbuhan luas daun, indeks luas daun, berat segar panen, dan indeks panen segar menggunakan metode oleh Sitompul dan Guritno (1995), sedangkan data hasil pengamatan dianalisis sesuai penyusunan rancangan lingkungan pada penelitian ini yang menggunakan Rancangan Acak Lengkap (RAL) satu faktor perlakuan (Mattjik dan Sumertajaya, 2002).

\section{HASIL DAN PEMBAHASAN}

\section{Hasil Pengamatan}

Hasil pengamatan pertumbuhan tanaman kangkung darat sebagai pengamatan visual (tinggi tanaman, jumlah daun dan luas daun) disajikan pada Tabel 1, sedangkan hasil analisis pertumbuhan tanaman sebagai pengamatan fisiologis (indeks luas daun, berat segar panen dan indeks panen segar) disajikan pada Tabel 2.

Berdasarkan Tabel 1 dan 2, adanya pemberian kapur dolomit di tanah gambut pada dosis 3-9 ton $\mathrm{ha}^{-1}$ dengan saat panen yang berbeda (umur 21 dan 28 HST) menunjukkan bahwa tanaman kangkung darat mempunyai pertumbuhan dan hasil yang bervariasi. Beberapa hasil pengamatan yang meliputi tinggi tanaman, jumlah daun, luas daun, indeks luas daun, berat segar panen dan indeks panen segar tanaman kangkung darat yang dapat dilakukan nampaknya 
Tabel 1. Pengamatan visual tanaman kangkung darat yang dibudidayakan di tanah gambut dengan perlakuan kapur dolomit

\begin{tabular}{cccccccc}
\hline \multirow{2}{*}{ No. } & Pemberian & \multicolumn{2}{c}{ Tinggi Tanaman (cm) } & \multicolumn{2}{c}{ Jumlah Daun (daun) } & \multicolumn{2}{c}{ Luas Daun (cm ${ }^{2}$ ) } \\
\cline { 3 - 8 } & Kapur Dolomit & 21 HST & 28 HST & 21 HST & 28 HST & 21 HST & 28 HST \\
\hline 1. & D1 $\left(3\right.$ ton $\left.\mathrm{ha}^{-1}\right)$ & 21.5 & 28.7 & 10 & 14 & 222,10 & 243,00 \\
2. & D2 $\left(6{\left.\text { ton } \mathrm{ha}^{-1}\right)}^{-1}\right.$ & 22.4 & 35.3 & 16 & 28 & 365,12 & 407,70 \\
3. & D3 $\left(9\right.$ ton $\left.\mathrm{ha}^{-1}\right)$ & 27.1 & 45.0 & 19 & 35 & 465,69 & 676,63 \\
\hline
\end{tabular}

Tabel 2. Pengamatan fisiologis tanaman kangkung darat yang dibudidayakan di tanah gambut dengan perlakuan kapur dolomit

\begin{tabular}{|c|c|c|c|c|c|c|c|}
\hline \multirow{2}{*}{ No. } & \multirow{2}{*}{$\begin{array}{c}\text { Pemberian } \\
\text { Kapur Dolomit }\end{array}$} & \multicolumn{2}{|c|}{ Indeks Luas Daun } & \multicolumn{2}{|c|}{ Berat Segar Panen (g) } & \multicolumn{2}{|c|}{ Indeks Panen Segar } \\
\hline & & $21 \mathrm{HST}$ & $28 \mathrm{HST}$ & $21 \mathrm{HST}$ & 28 HST & $21 \mathrm{HST}$ & $28 \mathrm{HST}$ \\
\hline 1. & D1 (3 ton ha $\left.{ }^{-1}\right)$ & 0,56 & 0,61 & 6.06 & 7.97 & 0.732 & 0.749 \\
\hline 2. & $\mathrm{D} 2\left(6\right.$ ton $\left.\mathrm{ha}^{-1}\right)$ & 0,91 & 1,02 & 9.55 & 12.91 & 0.754 & 0.752 \\
\hline 3. & D3 (9 ton ha $\left.{ }^{-1}\right)$ & 1,16 & 1,69 & 14.84 & 19.52 & 0.781 & 0.761 \\
\hline
\end{tabular}

mampu dihimpun sebagai informasi lapangan dan sekaligus mendorong untuk dilakukannya upaya mempertimbangkan saat panen yang baik dan menguntungkan berdasarkan pengamatan indikator pertumbuhan tanaman kangkung darat tersebut.

\section{Pembahasan}

Memperhatikan segala aspek budidaya tanaman hidroponik sayuran daun pada saat di lahan (on farm) sangatlah penting, namun memperhatikan saat panen yang tepat dan menguntungkan untuk tanaman sayuran daun merupakan upaya yang tak kalah pentingnya dilakukan karena bisa menjadikan budidaya menjadi lebih baik, praktis dan menguntungkan. Secara lebih baik adalah tetap mampu berproduksi dengan produktivitas yang tinggi. Begitu juga secara praktis adalah dengan masa panen yang lebih singkat menyebabkan menunjang dipenuhinya kebutuhan sayuran secara berkesinambungan. Sedangkan secara menguntungkan adalah hasil panen tetap berkualitas dan mempunyai nilai pasar yang tinggi sehingga tetap menarik dan layak jual. Sitompul dan Guritno (1995) menyatakan bahwa menentukan waktu panen tanaman adalah menjadi penting yaitu berhubungan dengan gambaran pertumbuhan tanaman. Penentuannya waktu yang menyangkut pertumbuhan tanaman ternyata dapat digunakan untuk penentuan waktu pengamatan, termasuk penetapan waktu panennya.

Berdasarkan Tabel 1 dan 2, pengamatan panen yang dilakukan adalah pada dua jenis umur tanaman yaitu pada umur 21 HST dan 28 HST. Pengamatan yang meliputi tinggi tanaman, jumlah daun, luas daun, indeks luas daun, berat segar panen dan indeks panen segar tanaman kangkung darat merupakan informasi visual dan fisiologis yang bisa digunakan sebagai bahan untuk mempertimbangkan waktu panen. Julianti (2013) menjelaskan bahwa penentuan waktu panen yang tepat bisa dilakukan dengan 
berdasarkan kriteria, yaitu bisa berdasarkan kriteria penampakan visual, indikator fisik, indikator kimia, indikator fisiologis dan komputasi. Ditambahkan oleh Wahyono et al. (2013) bahwa panen dilakukan bisa berdasarkan umur, ciri tanaman dan prediksi cuaca, namun semuanya berdasarkan pengalaman di lapangan (yaitu hasil pengamatan). Secara prinsip ada kriteria yang menjadi pertimbangan yaitu dilihat dari standar mutu, warna, fisik, dan ukurannya.

Mempertimbangkan waktu panen yang baik dan tepat tanaman sayuran daun ternyata perlu dilakukan karena memberikan gambaran kepastian berbudidaya, tetapi harus memiliki dasar dan pertimbangan yang ilmiah. Hal ini yang mendorong pentingnya menentukan waktu panen untuk tanaman kangkung darat yang dibudidayakan di tanah gambut khususnya akibat pemberian kapur dolomit. Penentuan waktu panen ini tidak hanya mendapatkan kapan tanman bisa dipanen, tetapi juga menyangkut beberapa keuntungan apabila bisa dilakukan berdasarkan data lapangan dan analisis pertumbuhannya.

Penampakan visual tanaman kangkung yang meliputi tinggi tanaman, jumlah daun dan luas daun (Tabel 1), memberikan gambaran pertumbuhan dan bisa digunakan sebagai pertimbangan kriteria penentuan saat panen. Apabila dilihat dari visual pertumbuhannya, maka tanaman kangkung darat yang dibudidayakan di tanah gambut dengan dipupuk menggunakan kapur dolomit 9 ton ha ${ }^{-1}$ sudah bisa memenuhi kriteria waktu panen pada umur 21 HST karena rata-rata telah memiliki pertumbuhan batang yang besar, tinggi, berdaun banyak dan luas, serta tingginya mendekati $20 \mathrm{~cm}$ dan bahkan telah melampaui $25 \mathrm{~cm}$ (Gambar 1). Hal ini sesuai dengan pendapat beberapa hasil penelitian dan panduan budidaya bahwa kangkung darat bisa dipanen apabila secara visual pertumbuhan batangnya sudah besar, berdaun banyak, dan tinggi tanamannya sudah mencapai $20-25 \mathrm{~cm}$, meskipun beberapa pendapat menyatakan bahwa kangkung sudah bisa dipanen pada umur sekitar 25-27 HST (Susila, 2006; Asnuri, 2014).

Pertumbuhan kangkung darat seperti yang nampak pada Gambar 1 menunjukkan bahwa pertumbuhan tanaman pada umur 21 HST tersebut telah memberikan gambaran kriteria yang secara visual yang mengarah kepada kondisi memungkinkannya kangkung darat untuk layak dipanen. Hal ini telah nampak berupa pertumbuhan visual batangnya yang baik dan daun yang telah lebat. Begitu juga secara profil memberikan gambaran bahwa apabila dipanen sudah memberikan tampilan sayuran yang menarik dan secara pasca panen pun layak sebagai bahan panen yang mudah dikelola dan dipasarkan. Kondisi yang terpenting adalah pertumbuhan tinggi tanamannya yang belum terlalu lanjut dan masih dalam kondisi tegak, sehingga terhindar dari kondisi rebah dan menjalar.

Berbeda dengan kondisi pertumbuhan tanaman kangkung darat pada umur 28 HST (Gambar 1), bahwa apabila dijadikan acuan sebagai waktu panen nampaknya pertumbuhannya secara visual memberikan gambaran kriteria yang perlu dipertimbangkan dan mungkin bahkan dihindari sebagai profil sayuran yang layak dipanen karena kondisi tampilan yang sudah mulai rebah dan menjalar, meskipun secara berat segar panennya memiliki 


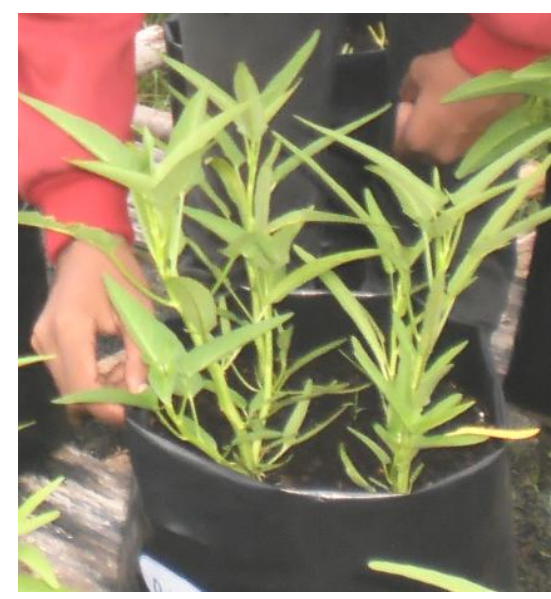

(A)

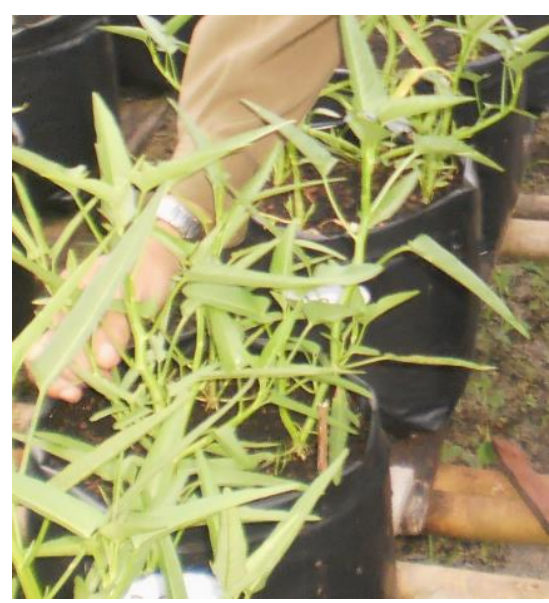

(C)

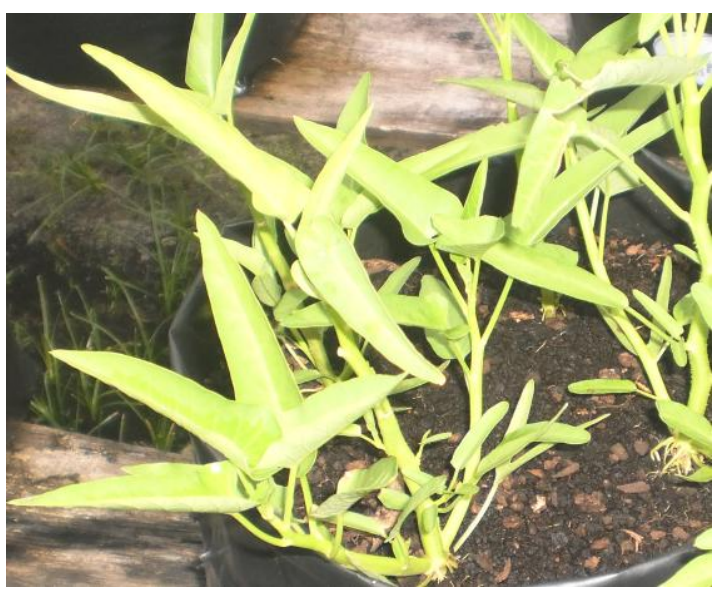

(B)

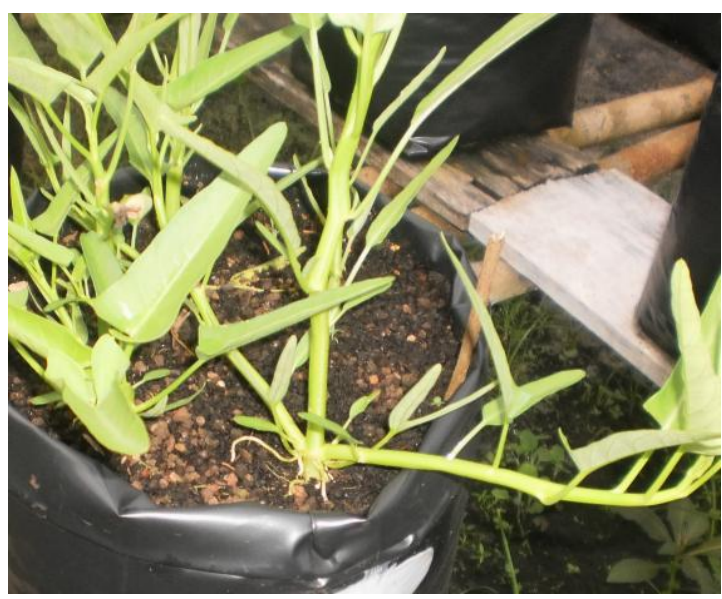

(D)

Gambar 1. Profil pertumbuhan secara visual tanaman kangkung darat yang dibudidayakan di tanah gambut dengan pemupukan kapur dolomit, (A) dan (B) pertumbuhan umur 21 HST (nampak tumbuh telah cukup baik dan tegak), (C) dan (D) pertumbuhan umur 28 HST (nampak tumbuh lebih lebat tapi menjalar dan cenderung rebah).

nilai berat segar panen yang lebih tinggi jika dibandingkan dengan saat panen umur 21 HST (Tabel 2). Hal ini juga perlu dikaji secara mendalam yang berhubungan dengan mudah tidaknya pengelolan pasca panen sayuran daun apabila dipanen pada umur $28 \mathrm{HST}$, termasuk menyangkut potensi tampilan sayuran saat di pasaran nantinya.
Berdasarkan Tabel 2, menunjukkan bahwa pengamatan pertumbuhan tanaman kangkung darat secara fisiologis, dalam hal ini menyangkut analisis pertumbuhan tanaman berupa indeks luas daun, berat segar panen dan indeks panen segar tanaman kangkung darat dihasilkan pada dua keadaan waktu analisis tumbuh dan waktu panen, yaitu pada umur $21 \mathrm{HST}$ dan $28 \mathrm{HST}$. Hal 
ini nampaknya semakin memberikan kelengkapan pertimbangan kriteria panen bahwa pada umur 21 HST tanaman kangkung darat yang dibudidayakan di tanah gambut dengan pemberian pupuk kapur dolomit sudah menunjukkan tanda-tanda secara fisiologis sudah mampu untuk dipanen. Kondisi ini dapat kita cermati berdasarkan hasil analisis pertumbuhan tanaman kangkung darat yang menyangkut nilai indeks luas daun (ILD) dan nilai indeks panen segarnya (IP).

Apabila dianalisis yang dapat dilihat dan dicermati dari nilai indeks luas daunnya pada umur 21 HST (Tabel 2), maka menunjukkan adanya penurunan nilai indeks panen segar dari 0,781 (21 HST) menjadi 0,761 (28 HST) pada perlakuan $D_{3}$. Penurunan nilai indeks panen segar ini diduga berhubungan dengan nilai indeks luas daun (ILD) tanaman kangkung darat yang secara waktu mengalami kenaikan nilainya dari 1,16 (pada umur 21 HST) menjadi 1,69 (pada umur 28 HST) sehingga berhubungan dengan efisiensi proses fotosintesis tanaman yang sudah mulai berkurang. Hal ini diindikasikan oleh gambaran pada umur 21 HST tersebut nilai ILD tanaman kangkung darat tersebut sudah melebihi dari nilai 1 yang artinya sebenarnya daun-daunan tanaman kangkung sudah mulai saling menutupi sehingga proses fotosintesis dan hasilnya oleh semua daun kurang maksimal lagi, apalagi setelah mengalami peningkatan dari ILD 1,16 menjadi 1,69.

Tabel 2 juga menunjukkan bahwa setelah umur 21 HST menuju 28 HST, nampaknya indeks panen segar tanaman kangkung darat mengalami penurunan, meskipun hasil panen segarnya mengalami peningkatan. Hal ini juga diduga adanya hubungan yang komprehensif diantara beberapa kondisi pertumbuhan yang saling mempengaruhi. Luasnya daun tanaman kangkung yang sedang giat tumbuh nampaknya menyebabkan peningkatan nilai indeks luas daun (ILD) yang juga mengakibatkan tingginya nilai indeks panen segar, namun bertambahnya waktu pertumbuhan nampaknya juga menyebabkan semakin bertambahnya nilai ILD yang menyebabkan menurunnya nilai indeks panen segar (IP) tanaman kangkung darat. Kondisi ini yang memberikan pertimbangan bahwa penentuan waktu panen tanaman kangkung darat sudah bisa dimulai pada umur $21 \mathrm{HST}$ dan profil visual tanaman dan hasil panennya masih tetap berkualitas. Nofriati (2013) menjelaskan bahwa melakukan panen yang berkualitas bisa dilakukan dengan menjaga kualitas sayuran daun sebelum panen dan saat panen, yang meliputi panen pada umur panen yang tepat (pada umumnya sayuran daun dapat dipanen 21 hari setelah tanam) dan melaksanakan panen pada indeks panen yang tepat (yaitu saat daun berwarna hijau terang dan tekstur batang tegar).

Apabila dianalisis secara fisiologis yang berhubungan dengan faktor tumbuh dari lingkungan, maka Tabel 1, Tabel 2 dan Gambar 1 menunjukkan adanya potensi layak panen tanaman kangkung darat berada pada umur 21 HST. Kondisi ini menunjukkan bahwa nampaknya tanaman kangkung saat memasuki umur 21 HST tersebut diduga berada pada kebutuhan satuan panas yang telah terpenuhi untuk pertumbuhan tanaman kangkung yang seumur pertumbuhannya pada umur 28 HST jika ditanam dan dipanen di saat umur 28 HST. Kondisi ini karena didukung suhu harian yang relatif tinggi sehingga menjadi faktor pemicu percepatan waktu 
panen tanaman kangkung apabila dibudidayakan di Palangka Raya. Hal ini sesuai dengan kondisi yang disampaikan oleh Sugito (1999) dan Kamillah (2006) bawa lamanya tahap budidaya dapat dihitung dan diprediksi dengan menggunakan jumlah rata-rata suhu harian untuk mengetahui jumlah panas yang merupakan akumulasi suhu sepanjang hari di atas suhu dasar minimum tanaman yang dibutuhkan oleh tanaman selama periode waktu tertentu untuk mencapai fase pertumbuhan tertentu dalam siklus hidupnya.

Memiliki dan melaksanakan waktu panen yang tepat pada tanaman sayuran daun akibat pertimbangan visual (tampilan) yang menarik dan analisis pertumbuhannya (fisiologis) ternyata selain mempertahankan produksi dan kualitas hasil panennya, juga mendapatkan keutungan secara ekonomi. Profil hasil panen yang bermutu termasuk memperhatikan tampilan fisik (visual), ternyata mempunyai keuntungan dari segi ekonomis, karena menurut Utama (2001) bahwa panen dengan saat yang tepat berhubungan dengan tampilan visual yang sederhana dan efektif memudahkan penanganan pasca panen sehingga menjamin mutu lebih tinggi, menghemat tenaga dan biaya, mengundang konsumen membeli dengan harga lebih (selera pasar) dan menghemat tata pemasaran. Hal ini penting dilakukan sebagai pertimbangan hubungan antara fisik hasil panen dan nilai ekonomis yang diberikan.

\section{KESIMPULAN DAN SARAN}

\section{Kesimpulan}

Berdasarkan hasil pengamatan dan uraian pembahasan, penelitian ini menghasilkan kesimpulan bahwa :

1. Pengamatan indikator visual dan fisiologis tanaman sayuran kangkung darat di tanah gambut akibat pemberian kapur dolimit bisa digunakan sebagai pertimbangan kriteria saat panen yang tepat dan menguntungkan.

2. Penilaian visual dan pertimbangan indikator fisiologis pertumbuhan tanaman kangkung cukup memberi pertimbangan kriteria panen tanaman sayur kangkung darat yang bisa dilakukan mulai umur 21 HST dan tidak perlu menunggu umur 28 HST pada semua dosis pemberian kapur yang diberikan (3-9 ton ha $\left.{ }^{-1}\right)$.

3. Panen tanaman sayur kangkung darat mulai umur $21 \mathrm{HST}$ telah memiliki indeks panen yang relatif tinggi sebesar 73,2-78,1\% meskipun panen segar di umur 28 HST juga mampu mencapai indeks panen sebesar 74,9$76,1 \%$ pada semua dosis pemberian kapur yang diberikan (3-9 ton $\mathrm{ha}^{-1}$ ).

\section{Saran}

Berdasarkan hasil pengamatan, uraian pembahasan, dan kesimpulan penelitian ini, maka disarankan bahwa :

1. Panen segar kangkung darat dengan cara dicabut sebaiknya dilakukan dimulai umur 21 HST apabila ditanam di tanah gambut menggunakan kapur dolomit dengan dosis 3-9 ton $\mathrm{ha}^{-1}$. 
2. Perlu pengkajian waktu panen tanaman kangkung darat secara kriteria lainnya pada kisaran antara waktu panen umur 21 HST sampai 28 HST.

\section{UCAPAN TERIMA KASIH}

Ucapan terima kasih disampaikan kepada Bondan Wiharja dan Muhammad Ruzi Gustyanwar selaku mahasiswa program studi Agroteknologi Fakultas Pertanian Universitas Muhammadiyah Palangkaraya yang bersedia terlibat penelitian bersama. Terimakasih juga disampaikan kepada Universitas Muhammadiyah Palangkaraya yang telah memfasilitasi dan membantu mendanai pembiayaan kegiatan penelitian ini pada Tahun Anggaran 2015.

\section{DAFTAR PUSTAKA}

Asnuri, 2014. Teknik Budidaya Sayuran. http://stppyogyakarta.ac.id/wpcontent/uploads/2014/10/AS-BUDIDAYASAYuran.pdf

Julianti, E., 2013. Panen dan Penanganan Pascapanen. https://elisajulianti.files.wordpress.com/201 3/06/panen-dan-penangananpascapanen.pdf

Kamillah, 2006. Penaksiran Waktu Berbunga dan Saat Panen Tanaman Kedelai Varietas Wilis Dengan Jumlah Panas (Heat-Sum). Jurnal Lamina. Volume 2, Nomor 2, Desember 2006, 55-62.

Luther, K. 2012. Panen dan Menyimpan Benih Sayur-sayuran : Buku Panduan Untuk Petani (terjemahan) dari Sutevee Sukprakarn, Sunanta Juntakool, Rukui Huang (Kasetsart University), dan Tom Kalb (AVRDC - The World Vegetable Center). 2012. Saving Your Own Vegetable Seeds - a Guide for Farmers. AVRDC -
The World Vegetable Center Publication. Shanhua, Tainan, Taiwan.

Mattjik, A. A. dan I.M. Sumertajaya. 2002. Perancangan Percobaan dengan Aplikasi SAS dan Minitab. Jilid I Edisi Ke-dua. IPB PRESS. Bogor.

Nofriati, D. 2013. Teknologi Pascapanen Sayuran Daun. Balai Pengkajian Teknologi Pertanian (BPTP) Jambi. Jambi.

Sitompul, S.M., dan B. Guritno, 1995. Analisis Pertumbuhan Tanaman. Gadjah Mada University Press. Yogyakarta.

Sugito, Y., 1999. Ekologi Tanaman. Fakultas Pertanian, Universitas Brawijaya, Malang

Susila, A. D., 2006. Panduan Budidaya Tanaman Sayuran. Departemen Agronomi dan Hortikultura Fakultas Pertanian Institut Pertanian Bogor. Bogor.

Utama, I. M. S. dan N. S. Antara, 2013. Pasca Panen Tanaman Tropika : Buah dan Sayur. Tropical Plant Curriculum Project. Udayana University. Denpasar, Bali.

Utama, I. M. S., 2001. Penanganan Pascapanen Buah dan Sayuran Segar. Makalah : "Forum Konsultasi Teknologi" Dinas Pertanian Tanaman Pangan Provinsi Bali, di Hotel Puri Bali Utama Denpasar Tgl 21 Nopember 2001. Universitas Udayana. Denpasar, Bali.

Wahyono, E.H., H.R. Sadjudin, B.R. Soetrisno, N. Sudarno, Jueni, E. Hidayat, B. Lesmana, A. Arika J, Bonaji, Erwindo, Suhadi dan Sutarto. 2013. Pertanian Alami : Budidaya Sayuran Alami. Konsorsium YABI-WCSYAPEKA. Bogor. 